\title{
STRUKTUR PASAR SAYURAN KEMANGI DI PASAR TRADISIONAL
}

\author{
W. Nahraeni ${ }^{1 \mathrm{a}}$, A. Rahayu ${ }^{2}$, A. Yoesdiarti ${ }^{1}$ dan IA. Kulsum ${ }^{1}$ \\ ${ }^{1}$ Jurusan Agribisnis, Fakultas Pertanian, Universitas Djuanda Bogor \\ ${ }^{2}$ Jurusan Agroteknologi, Fakultas Pertanian, Universitas Djuanda Bogor \\ Jl. Tol Ciawi No 1 Universitas Djuanda Bogor Kode Pos 16720 \\ ${ }^{a}$ Korespondensi: Wini Nahraeni. Telp: 08129682305; E-mail: wini.nahraeni@unida.ac.id
}

\begin{abstract}
ABSTRAK
Sayuran indijenes memegang peranan penting dalam pertanian dan konsumsinya semakin meningkat seiring dengan pertambahan jumlah penduduk dan meningkatnya restaurant-restauran Sunda. Kemangi merupakan sayuran yang potensial dalam kontribusinya terhadap peningkatan pendapatan petani di perdesaan dan meningkatkan gizi keluarga. Tanaman ini mudah ditanam dan hanya memerlukan input eksternal yang rendah, dibandingkan dengan sayuran eksotis. Namun, meskipun tanaman ini penting, kemangi tidak cukup berorientasi pasar karena kecilnya daya saing petani dan terbatasnya produktivitas. Penelitian ini bertujuan untuk menganalisis struktur pasar sayuran kemangi. Data dikumpulkan dari 42 orang petani kemangi di Kecamatan Kadudampit (Desa Undruswinangun dan Sukamaju) yang diambil secara acak sederhana (simple random sampling), dan 29 orang pedagang yang diambil secara snowball sampling. Data dianalisis secara deskriptif dan kuantitatif. Analisis yang digunakan adalah pangsa pasar, konsentrasi pasar (CR), HHI (Herfindal-Hirscman Index), karakteristik produk, dan hambatan masuk pasar. Hasil penelitian menemukan bahwa pemasaran sayuran kemangi di Kecamatan Kadudampit didominasi oleh empat pedagang pengumpul desa terbesar dengan angka Concentration Ratio (CR4) sebesar 81\%. Nilai Herfindahl-Hirscman-Index sebesar 0,17 menunjukkan struktur yang terbentuk cenderung mengarah kepada kondisi pasar oligopoli dari sisi penjual sedangkan oligopsoni dari sisi pembeli. Nilai $M E S$ yang diperoleh di atas nol (MES $>0$ ) menunjukkan terdapat hambatan masuk pasar, dan karakteristik sayuran kemangi di Kecamatan Kadudampit bersifat homogen. Untuk meningkatkan posisi tawar petani, disarankan untuk membentuk kelompok tani kemangi, dan petani aktif mencari informasi pasar.
\end{abstract}

Kata kunci: Indijenes, Herfindal-Hirscman Index, Oligopoly. 


\section{PENDAHULUAN}

Peluang pengembangan sayuran indijenes memiliki prospek yang baik, seiring dengan pertambahan penduduk dan meningkatnya restaurant- restauran Sunda. Tanaman indijenes mudah ditanam, toleran terhadap berbagai kondisi tanah dan iklim, resisten terhadap hama dan penyakit dan dapat menambah pendapatan keluarga. Selain itu tanaman indijenes mampu tumbuh dengan input eksternal yang rendah (1) Upaya pengembangan sayuran indijines juga dilakukan sebagai alternatif sumber mikronutrien (zat berkhasiat) murah dan sekaligus memperkuat basis ketahanan pangan (2) Kemangi merupakan salah satu jenis sayuran indijenes yang mempunyai banyak manfaat dan permintaannya relatif lebih besar dari sayuran indijenes lainnya. Salah satu sentra produksi kemangi di Kabupaten Sukabumi adalah Kecamatan Kadudampit.

Meskipun kemangi ini cukup berkontribunsi terhadap pendapatan, namun petani belum berorientasi pasar. Proses pemasaran kemangi mempunyai keunikan, di antaranya fluktuasi harga yang relatif stabil, dan cara menjual berbeda dengan sayuran pada umumnya sebab kemangi dijual per gabung, per ikat, hingga per gantil jika sudah sampai ke tingkat pedagang keliling. Perbedaan ini menyebabkan perbedaan harga yang relatif tinggi dari pedagang pengumpul sampai pedagang eceran. Selain itu terbatasnya akses petani ke pasar, informasi pasar yang kurang, dan skala usaha yang relatif kecil menjadikan dukungan yang ditawarkan terbatas.

Struktur pasar adalah penggolongan pasar berdasarkan strukturnya yang dapat dilihat dari jumlah produsen dan konsumen, karakteristik produk, mudah tidaknya keluar masuk pasar, dan ada tidaknya informasi pasar (Case and Fair (2012), Pindyct dan Rubinfield ( 2009). Dengan mengetahui struktur pasar, maka dapat dilihat apakah pasar mengarah ke pasar persaingan sempurna (perfect market) atau persaingan tidak sempurna (imperfect market). Studi yang dilakukan oleh Kirsten (2010) menyatakan bahwa akses ke pasar merupakan factor penting untuk meningkatkan kinerja petani skala kecil di negara berkembang. Sementara itu penelitian Erwidodo (2013) menyatakan bahwa struktur pasar kentang, bawang merah dan kubis adalah pasar persaingan sempurna, yang dicirikan oleh banyaknya pembeli dan penjual dan pembeli secara perorangan tidak dapat sesukanya menentukan harga di pasar. Penelitian struktur pasar sayuran indijenes khususnya kemangi relatif terbatas, oleh karena itu penelitian struktur pasar sayuran kemangi perlu dilakukan sebagai upaya untuk meningkatkan posisi tawar petani.

Pasar adalah penghubung antara produsen dan konsumen, tanpa pasar petani tidak akan memiliki insentif untuk terlibat dalam produksi tanaman kemangi. Dalam memasarkan produknya, petani di Kecamatan Kadudampit masih belum berorientasi pasar. Hal ini terlihat dari kurangnya partisipasi mereka dalam memasarkan kemanginya dan masih beroperasi pada kondisi yang homogen, sehingga posisi tawar menjadi rendah. Petani hanya menerima harga yang ditawarkan para pedagang pengumpul karena kurangnya informasi pasar. Pertanyaannya adalah bagaimana struktur pasar yang ada dapat mempengaruhi harga pada berbagai lembaga dalam rantai pemasaran? Penelitian ini bertujuan untuk menganalisis struktur pasar sayuran kemangi di Kecamatan Kadudampit Sukabumi Jawa Barat.

\section{BAHAN DAN METODE}

\section{Metode Pengumpulan Data}

Pengumpulan data dilaksanakan di Kecamatan Kadudampit pada bulan April sampai Mei 2017. Desa Sukamaju dan Desa Undrus Binangun dipilih sebagai sampel desa. Pemilihan lokasi penelitian ditentukan secara sengaja (purposive), dengan pertimbangan kedua desa tersebut merupakan sentra produksi kemangi di Kabupaten Sukabumi. 
Metode Pengambilan Sampel

Pengambilan petani sampel dilakukan dengan menggunakan metode acak sederhana (simple random sampling), dengan jumlah petani yang diambil sebagai sampel sebanyak 42 orang. Pengambilan responden pedagang dilakuka dengan metode snowball sampling Jumlah pedagang yang diambil responden sebanyak 29 orang, yang terdiri atas 6 pedagang pengumpul desa, 6 pedagang besar dan 17 pedagang pengecer.

\section{Metode Pengolahan dan Analisis Data}

Data yang dikumpulkan dalam penelitian ini adalah data primer dan data sekunder. Data primer diambil dengan wawancara langsung menggunakan kuesioner yang telah ditetapkan terlebih dahulu, sedangkan data sekunder diambil dari BPS, Dinas Pertanian Tanaman Pangan dan Hortikultura, Jurnal dan literatur lainnya. Data dianalisis dengan menggunakan metode deskriptif dan kuantitatif, dan diolah dengan menggunakan excel dan SPSS 21. adalah:

Beberapa alat analisis struktur pasar

\section{Pangsa Pasar}

Pangsa pasar digunakan untuk mengetahui seberapa besar cakupan suatu industri di pasaran. Pangsa pasar dapat diukur dengan menggunakan rumus: Dahl, D.C, J.W. Hammond. 1977

$$
\text { Market Share }(\mathrm{MS})=\mathrm{S}_{\mathrm{i}} / \mathrm{S}_{\mathrm{T}}
$$

Keterangan:

MS $=0-100 \%$;

$\mathrm{S}_{\mathrm{i}} \quad=$ Penjualan pedagang pengumpul terbesar ke i

$\mathrm{S}_{\mathrm{T}} \quad=$ Penjualan total sayuran kemangi di Kecamatan Kadudampit.

\section{Konsentrasi Pasar}

Konsentrasi pasar mengukur berapa jumlah output yang diproduksi dari empat perusahaan terbesar dalam sebuah industri (Baye, 2010). Konsentrasi pasar dapat diukur dengan rumus:

$$
\begin{gathered}
\mathrm{CR}_{4}=\mathrm{S}_{1}+\mathrm{S}_{2}+\mathrm{S}_{3}+\mathrm{S}_{4} / \mathrm{S}_{\mathrm{T}} \\
\quad \text { atau } \\
\mathrm{CR}_{4}=\mathrm{w}_{1}+\mathrm{w}_{2}+\mathrm{w}_{3}+\mathrm{w}_{4}
\end{gathered}
$$

Keterangan :

$\mathrm{CR}_{4}=$ Tingkat Konsetrasi Pasar

$\mathrm{Wi}=\mathrm{S}_{\mathrm{i}} / \mathrm{S}_{\mathrm{T}} ; \mathrm{I}=1,2,3,4$

\section{HHI (Herfdinal-Hirscman Index)}

Selain menggunakan persamaan 2, konsentrasi pasar dapat dihitung dengan menggunakan HHI (Herfdinal-Hirscman Index). HHI merupakan penjumlahan kuadrat dari pangsa pasar petani dalam suatu industri dikalikan dengan 10.000. Adapun perhitungan $\mathrm{HHI}$ yaitu:

$$
\mathrm{HHI}=\Sigma w i^{2}
$$

Keterangan:

$\mathrm{HHI}=$ Herfindahl Hirschman Index;

wi $^{2}=$ Pangsa pasar

\section{Hambatan Masuk Pasar}

Hambatan masuk pasar dianalisis dengan menggunakan Minimun Effisiency Scale (MES) (Wahyuningsih, 2013). Nilai MES dapat diketahui melalui rumus sebagai berikut:

$$
M E S=\frac{\text { Penjualan PPD terbesar }}{\text { Produksi kemangi }} x 100 \%
$$

\section{HASIL DAN PEMBAHASAN}

\section{Karakteristik Petani Sampel}

Berdasarkan hasil penelitian, dari 42 orang petani sampel, sebagian besar petani (33\%) berada pada kelompok umur antara 51-60 tahun, $86 \%$ petani berjenis kelamin laki-laki, berpendidikan SD /sederajat (55\%), pengalaman berusaha tani sekitar 10 tahun lebih (81\%), sedangkan pengalaman usahatani sayuran indigenous khususnya kemangi, sebagian besar petani mempunyai pengalaman berusahatani $1-5$ tahun (50\%). Berdasarkan jumlah tanggungan keluarga, persentase terbesar yaitu sebanyak 48\% mempunyai jumlah tanggungan keluarga 0 sampai 2 orang dan 3 sampai 5 orang. 
Karakteristik Responden Pedagang

Lembaga pemasaran yang terlibat adalah pedagang pengumpul desa (PPD), pedagang besar (PD) dan pengecer. Berdasarkan umur, sebagian besar $(83 \%)$ PPD berumur antara 20-40 tahun, hampir sama dengan pedagang besar (PB), namun umur pengecer sebagian besar berumur lebih dari 40 tahun. $\mathrm{PB}$ dan pengecer mempunyai pengalaman berdagang 6-10 tahun $(33,3 \%$ dan $35,3 \%)$, sedangkan sebagian besar PPD mempunyai pengalaman berdagang 11-15 tahun. Tingkat pendidikan PPD sangat bervariasi yaitu tamat Sekolah Dasar (SD) 4 orang, tamat SLTP/sederajat 1 orang, dan tamat SLTA/sederajat 1 orang, dapat disimpulkan bahwa tingkat pendidikan rata-rata pedagang pengumpul desa adalah tamat Sekolah Dasar (SD) yaitu sebesar $66,7 \%$.

Tabel 1 Karakteristik Lembaga Pemasaran di Kecamatan Kadudampit, 2017

\begin{tabular}{|c|c|c|c|c|c|c|}
\hline \multirow{3}{*}{ Karakteristik } & \multicolumn{6}{|c|}{ Lembaga Pemasaran } \\
\hline & \multicolumn{2}{|c|}{ PPD } & \multicolumn{2}{|c|}{ PB } & \multicolumn{2}{|c|}{ Pengecer } \\
\hline & Jumlah & $\%$ & Jumlah & $\%$ & Jumlah & $\%$ \\
\hline \multicolumn{7}{|l|}{ Umur (Tahun) } \\
\hline - $20-40$ & 5 & 83,3 & 3 & 50 & 5 & 29,4 \\
\hline - $>40$ & 1 & 16,7 & 3 & 50 & 12 & 70,6 \\
\hline Jumlah & 6 & 100 & 6 & 100 & 17 & 100 \\
\hline \multicolumn{7}{|l|}{ Pengalaman Berdagang (Tahun) } \\
\hline$\bullet 0-5$ & 1 & 16,7 & 0 & 0 & 3 & 17,6 \\
\hline - $6-10$ & 0 & 0 & 2 & 33,3 & 6 & 35,3 \\
\hline - $11-15$ & 4 & 66,7 & 1 & 16,7 & 1 & 5,9 \\
\hline - $16-20$ & 1 & 16,7 & 2 & 33,3 & 3 & 17,6 \\
\hline - $\quad>20$ & 0 & 0 & 1 & 16,7 & 4 & 23,5 \\
\hline Jumlah & 6 & 100 & 6 & 100 & 17 & 100 \\
\hline \multicolumn{7}{|c|}{ Pengalaman Berdagang Sayuran Indigenous (Tahun) } \\
\hline$\bullet 0-5$ & 1 & 16,7 & 2 & 33,3 & 5 & 29,4 \\
\hline - $6-10$ & 3 & 50 & 1 & 16,7 & 7 & 41,2 \\
\hline - $11-15$ & 2 & 33,3 & 1 & 16,7 & 1 & 5,9 \\
\hline - $16-20$ & 0 & 0 & 2 & 33,3 & 3 & 17,6 \\
\hline - $>20$ & 0 & 0 & 0 & 0 & 1 & 5,9 \\
\hline Jumlah & 6 & 100 & 6 & 100 & 17 & 100 \\
\hline \multicolumn{7}{|l|}{ Pendidikan } \\
\hline - $\quad$ Tidak Tamat SD/sederajat & 0 & 0 & 2 & 33,3 & 3 & 17,6 \\
\hline - Tamat SD/sederajat & 4 & 66,7 & 1 & 16,7 & 6 & 35,3 \\
\hline - Tamat SLTP & 1 & 16,7 & 2 & 33,3 & 2 & 11,8 \\
\hline - Tamat SLTA & 1 & 16,7 & 1 & 16,7 & 6 & 35,3 \\
\hline - Diploma/Sarjana muda & 0 & 0 & 0 & 0 & 0 & 0 \\
\hline - Sarjana/Pascasarjana & 0 & 0 & 0 & 0 & 0 & 0 \\
\hline Jumlah & 6 & 100 & 6 & 100 & 17 & 100 \\
\hline \multicolumn{7}{|l|}{ Status Mata Pencaharian } \\
\hline - Sebagai Pekerjaan Utama & 6 & 100 & 6 & 100 & 15 & 88,2 \\
\hline - Sebagai Pekerjaan Sampingan & 0 & 0 & 0 & 0 & 2 & 11,8 \\
\hline Jumlah & 6 & 100 & 6 & 100 & 17 & 100 \\
\hline \multicolumn{7}{|l|}{ Jumlah Tanggungan Keluarga } \\
\hline - $0-2$ Orang & 2 & 33,3 & 4 & 66,7 & 7 & 41,2 \\
\hline - 3 - 5 Orang & 4 & 66,7 & 2 & 33,33 & 9 & 53 \\
\hline - 6 - 8 Orang & 0 & 0 & 0 & 0 & 1 & 5,9 \\
\hline Jumlah & 6 & 100 & 6 & 200 & 17 & 100 \\
\hline
\end{tabular}


Berdasarkan jenis pekerjaan, baik PPD maupun PB menyatakan bahwa berdagang sayuran merupakan pekerjaan utama (100\%), namun $11,8 \%$ pendagang pengecer menyatakan sebagai pekerjaan sampingan, kedua sampel tersebut memiliki pekerjaan utama sebagai pedagang ayam potong dan es. Hal ini menunjukkan bahwa pertanian menjadi sektor yang memiliki andil besar dalam membangun perekonomian dan meningkatkan kesejahteraan masyarakat.

\section{Market Structure (Struktur Pasar)}

\section{Konsentrasi Pasar}

Perhitungan konsentrasi pasar atau market concentration (CR) dilakukan pada pedagang pengumpul di tingkat dusun atau desa (Wahyuningsih, 2013). Tabel 2 menyajikan volume penjualan pedagang pengumpul desa sayuran kemangi di Kecamatan Kadudampit.

Tabel 2. Volume Penjualan Kemangi di Seluruh Pedagang Pengumpul Desa Kecamatan Kadudampit, 2017

\begin{tabular}{rc}
\hline Pedagang Pengumpul Desa (PDD) & Volume Penjualan (Ikat) \\
\hline PDD 1 & 35.400 \\
PDD 2 & 30.150 \\
PDD 3 & 62.208 \\
PDD 4 & 21.150 \\
PDD 5 & 57.360 \\
PDD 6 & 60.240 \\
\hline Total penjualan seluruh PDD & 266.508 \\
\hline
\end{tabular}

Hasil perhitungan disajikan pada Tabel 3. Berdasarkan nilai $\mathrm{CR}_{4}$ pedagang pengumpul desa sayuran kemangi di Kecamatan Kadudampit tahun 2017 diperoleh angka 81\%, angka ini menujukkan bahwa pemasaran sayuran kemangi di Kecamatan Kadudampit didominasi oleh empat pedagang pengumpul desa terbesar

Tabel 3. Volume Penjualan, Pangsa pasar, dan Rasio Empat Pedagang Pengumpul Desa $\left(\mathrm{CR}_{4}\right)$ untuk Periode Produksi Kemangi selama Enam Bulan di Kecamatan kadudampit, 2017

\begin{tabular}{cccc}
\hline Pedagang Pengumpul Desa & $\begin{array}{c}\text { Volume Penjualan } \\
\text { (Ikat) }\end{array}$ & $\begin{array}{c}\text { Pangsa pasar } \\
\left(\mathrm{S}_{\mathrm{n}}\right)\end{array}$ & $\begin{array}{c}\text { Persentase } \\
(\%)\end{array}$ \\
\hline PPD 1 $\left(\mathrm{w}_{1}\right)$ & 35.400 & 0,13 & 13 \\
PPD 2 $\left(\mathrm{w}_{2}\right)$ & 62.208 & 0,23 & 23 \\
PPD 3 $\left(\mathrm{w}_{3}\right)$ & 57.360 & 0,22 & 21 \\
PPD 4 $\left(\mathrm{w}_{4}\right)$ & 60.240 & 0,23 & 22 \\
Penjualan Total 4 PPD & 215.208 & - & - \\
Konsentrasi $\left(\mathrm{CR}_{4}\right)$ & - & 0,81 & 81 \\
\hline
\end{tabular}

Menurut Baye (2010) nilai $\mathrm{CR}_{4}$ yang mendekati 1 mengindikasikan bahwa pasar terkonsentrasi, artinya lebih sedikit jumlah penjual dibandingkan jumlah pembeli. Angka ini menunjukkan bahwa terdapat persaingan yang kecil antar pedagang. Di daerah penelitian, hal ini disebabkan oleh eratnya hubungan langganan antara penjual dan pembeli.

Perhitungan konsentrasi pasar dilakukan juga menggunakan HerfindahlHirscman-Index (HHI). Tabel 4 menunjukkan bahwa nilai HHI yang diperoleh dalam pemasaran sayuran 
kemangi di Kecamatan Kadudampit lebih besar dari 0, artinya bahwa pasar terkonsentrasi, hal ini sesuai dengan pendapat Baye (2010), jika nilai HHI 0, maka terdapat perusahaan-perusahaan dalam industri yang sangat kecil. Namun, jika nilai di atas 0 hingga 10000 (> 010.000) mengindikasikan bahwa pangsa pasarnya bernilai 1 , artinya $\mathrm{CR}$ berada pada sedikit persaingan untuk menjual ke konsumen (pasar terkonsentrasi).

Tabel 4. Perhitungan Herfindahl-Hirscman-Index di Kecamatan kadudampit Tahun 2017

\begin{tabular}{|c|c|c|}
\hline $\mathrm{W}_{\mathrm{n}}$ & $\mathrm{S}_{\mathrm{n}} / \mathrm{ST}$ & $\mathrm{wi}^{2}$ \\
\hline $\mathrm{w}_{1}$ & 0.133 & 0.018 \\
\hline $\mathrm{w}_{2}$ & 0.233 & 0.054 \\
\hline $\mathrm{w}_{3}$ & 0.215 & 0.046 \\
\hline $\mathrm{w}_{4}$ & 0.226 & 0.051 \\
\hline HUI - $10000 \Gamma_{\text {wi2 }}^{2}$ & HHI & 0,17 \\
\hline
\end{tabular}

Struktur pasar yang terbentuk dari pemasaran sayuran kemangi di tingkat pedagang pengumpul desa di Kecamatan Kadudampit cenderung bersifat oligopoli, yaitu pasar dengan beberapa penjual. Hal ini sesuai dengan pendapat Kohls dan Uhl (2002) yang menyatakan bahwa apabila nilai $\mathrm{CR}_{4}$ perusahaan terbesar lebih dari 50 persen $(>50 \%)$, maka struktur yang terbentuk cenderung mengarah kepada kondisi pasar oligopoli dari sisi penjual sedangkan oligopsoni dari sisi pembeli. Indiastuti (2011) memperkuat bahwa ada 6 kategori pasar berdasarkan tingkat persaingan yang diindikasikan oleh penguasaan pangsa pasar yaitu:

1. Pure Monopoly, satu perusahaan menguasai pangsa pasar $100 \%$.

2. Dominant Firm, satu perusahaan menguasai 40-99\%.

3. Tight Oligopoly, empat perusahaan menguasai pangsa pasar lebih dari 60 $\%$.

4. Loose Oligopoly, empat perusahaan menguasai pangsa pasar kurang dari 60 $\%$.

5. Monopolistic Competition, banyak perusahaan bersaing dengan masingmasing memiliki market power yang tidak sama.

6. Pure Competition, banyak perusahaan bersaing dengan masing-masing tidak memiliki market power.
Dengan demikian dapat dikatakan bahwa petani kemangi cenderung bertindak sebagai penerima harga (price taker) dan posisi tawar (bergainning position) petani lemah atau kurang memiliki kekuatan dalam menentukan harga jual kemangi. Sedikitnya jumlah pembeli dan semakin terkonsentrasi distribusi pembelian produk, maka semakin tinggi kekuatan pasar yang dimiliki oleh pembeli, sehingga pembeli berperan besar dalam penentuan harga. Atau dapat pula dikatakan semakin sedikit jumlah penjual dibandingkan jumlah pembeli, semakin terkonsentrasi distribusi penjualan produk, maka semakin tinggi pula kekuatan pasar yang dimiliki oleh penjual, dalam keadaan ini penjual berperan besar dalam penentuan harga. Hal ini berarti petani berada pada posisi yang lemah karena petani bertindak sebagai price taker.

Pada pemasaran sayuran indigenous kemangi di Kecamatan Kadudampit, kekuatan petani dalam menentukan harga jual cenderung lemah, sebab petani hanya menerima harga (price taker) yang dibayarkan oleh pembeli (PPD, PB, Pengecer) setelah kemangi berhasil dipasarkan, sedangkan informasi harga yang diperoleh hanya berupa informasi yang berasal langsung dari mulut pembeli bukan informasi yang berasal dari pasar, oleh karenanya besar kemungkinan 
terjadinya kepalsuan informasi terutama informasi harga. Ketiadaan lembaga penunjang kegiatan pertanian seperti kelompok tani atau terminal agribisnis semakin lemah penyampaian informasi ke petani.

\section{Hambatan Masuk Pasar}

Menurut keterangan para pedagang pengumpul di Kecamatan Kadudampit, hambatan yang banyak dihadapi dalam memasarakan kemangi adalah banyaknya pedagang yang membeli langsung dari petani baik sesama pedagang pengumpul, pedagang besar, atau pedagang pengecer, sehingga pedagang pengumpul desa yang telah ada bersaing dalam mendapatkan suplai kemangi dari petani ataupun menjual kepada konsumen. Keadaan demikian akan berdampak pada harga yang diterima oleh petani.

Hambatan masuk pasar dihitung dengan menggunakan MES Minumum Efficiency Scale (MES). Jika nilai MES lebih besar dari 10 persen, mengindikasikan bahwa terdapat hambatan masuk pada pemasaran sayuran kemangi di Kecamatan Kadudampit. Jika hambatan masuk tinggi, maka tingkat persaingannya sangat rendah, dan pasar berada pada kondisi kurang efisien (Jaya, 2001).

Tabel 5. Nilai MES Pemasaran Sayuran Indgenous Kemangi di Kecamatan Kadudampit, 2017

\begin{tabular}{lc}
\hline \multicolumn{1}{c}{ Lembaga Pemasaran } & Nilai MES (\%) \\
\hline PPD & 23,3 \\
PP & 28,7 \\
Pedagang Pengecer & 18,3 \\
\hline
\end{tabular}

Berdasarkan hasil analisis nilai MES pemasaran sayuran kemangi di Kecamatan Kadudampit di semua tingkat lembaga pemasaran mempunyai nilai lebih dari 10 persen. Hal ini menunjukkan bahwa terdapat hambatan masuk pasar pada pemasaran sayuran kemangi di Kecamatan Kadudampit sehingga tidak mudah bagi pesaing baru untuk masuk ke dalam pasar. Sulitnya masuk pasar ini disebabkan oleh kuatnya ikatan antara petani dan pedagang pengumpul desa sebagai langganan. Kuatnya ikatan tersebut disebabkan adanya ikatan modal antara petani dengan pedagang pengumpul desa, dan kuatnya ikatan hubungan kekeluargaan atau tetangga.

$$
\text { Besarnya nilai MES yang }
$$
dihasilkan berbeda antara MES yang dihasilkan di tingkat pedagang pengumpul desa, di tingkat pedagang besar, dan di tingkat pedagang pengecer, hal ini disebabkan adanya perbedaan hambatan untuk masuk pasar pada masing-masing tingkatan. Nilai MES terbesar diperoleh pada tingkat pedagang besar, sebab menjadi pedagang besar selain hambatan yang telah disebutkan, terdapat hambatan modal yang cukup besar. Modal ini digunakan untuk membeli hasil panen petani dan operasional dalam pemasaran, karena volume penjualan pedagang besar relatif lebih besar dibandingkan pedagang pengumpul desa dan pedagang pengecer. Hal ini juga berdampak pada biaya yang dikeluarkan relatif lebih besar pula sehingga akan mempengaruhi kemampuan pesaing baru untuk masuk ke dalam pasar.

Nilai MES terkecil diperoleh pada tingkat pedagang pengecer, sebab di tingkat pedagang pengecer hambatan masuk pasar relatif lebih ringan. Hambatan masuk pasar di tingkat pedagang pengecer sama halnya dengan hambatan di tingkat pedagang pengumpul dan di tingkat pedagang pengecer, akan tetapi ikatan penjual dan pembeli di tingkat pedagang pengecer relatif lebih renggang karena pembeli di pasar bebas memilih melakukan pembelian dengan pedagang pengecer mana pun, namun ada pula sebagian yang melakukan ikatan langganan. Akan tetapi di tingkat pedagang pengecer, volume yang dijual tidak dapat sebesar volume penjual di tingkat pedagang pengumpul desa dan di tingkat pedagang besar, sebab pedagang pengecer menjual langsung kepada konsumen dan pembelian konsumen biasanya lebih sedikit. 
Hambatan masuk pasar lainnya pada setiap tingkatan lembaga pemasaran adalah berlakunya sistem pembayaran tunda bayar atau bayar kemudian. Pembayaran dengan sistem ini akan menunda perputaran modal yang digunakan dalam usaha terkecuali pemilik modal besar yang dapat menggulirkan modalnya setiap saat. Tertunda atau berkurangnya perguliran modal usaha oleh setiap tingkatan lembaga pemasaran ini akan mengurangi kinerja setiap kegiatan pemasaran, sebagai contoh modal dalam pembelian saprotan, ketika pembayaran ditunda, maka petani akan meminjam modal kepada pihak lain seperti toko saprotan, dan ketika pembayaran dilakukan harga yang diharapkan tidak sesuai dengan kenyataan sehingga penerimaan petani berkurang.

\section{Karakteristik Produk}

Produk yang dihasilkan pada pemasaran sayuran kemangi di Kecamatan Kadudampit bersifat homogen. Sukirno (2002), menyebutkan ciri-ciri pasar oligopoly adalah barang yang dihasilkan bersifat homogen atau berbeda corak (terdiferensiasi), kekuasaan menentukan harga adakalanya lemah dan adakalanya kuat, pada umumnya perusahaan melakukan promosi dengan iklan. Nuhfil (2009), menyatakan pasar dalam keadaan produk yang dihasilkan bersifat homogen ini dinamakan oligopoli murni (pure oligopoly) dan apabila produk yang dihasilkan tidak homogen maka pasar dinamakan oligopoli yang dibedakan (differentiated oligopoly).

\section{KESIMPULAN DAN IMPLIKASI KEBIJAKAN}

\section{Kesimpulan}

Struktur pasar yang terbentuk dari pemasaran sayuran indigenous kemangi di Kecamatan Kadudampit cenderung mengarah kepada oligopoli. Pasar sayuran kemangi terkonsentrasi dengan persaingan yang cukup tinggi, dengan besarnya nilai $\mathrm{CR}_{4}$ 0,81 (mendekati 1) dan nilai $\mathrm{HHI}$ sebesar 1.700 (di atas 0 hingga 10 000) serta nilai MES seluruh tingkatan lembaga pemasaran lebih besar dari 10 persen. Terdapat hambatan masuk pasar bagi pesaing baru. Karakteristik produk yang diperjualbelikan bersifat homogen.

\section{Implikasi Kebijakan}

Untuk memperkuat posisi tawar petani diharapkan terminal-terminal agribisnis atau kelompok tani dihidupkan dan dikembangkan. Posisi tawar petani yang kuat dapat meningkatkan harga kemangi, yang pada akhirnya dapat meningkatkan penerimaan petani kemangi.

\section{DAFTAR PUSTAKA}

Asmayanti. 2012. Sistem Pemasaran Cabai Rawit Merah (Capsicum frustescens) di Desa Cigedug Kecamatan Cigedug Kabupaten Garut. Departemen Agribisnis. Fakultas Ekonomi dan Manajemen. Institut Pertanian Bogor: Bogor.

Badan Pengkajian dan Pengembangan Kebijakan Perdagangan Kementrian Perdagangan Republik Indonesia. 2015. Analisis Perkembangan Harga Bahan Pangan Pokok di Pasar Domestik dan Internasional. Kemendag.go.id. Diakses pada 28 Februari 2017.

Badan Pusat Statistik Provinsi Jawa Barat. 2013. Jawa Barat dalam Angka. https://jabar.bps.go.id. Diakses pada 13 Desember 2016.

Badan Pusat Statistik Provinsi Jawa Barat. 2014. Jawa Barat dalam Angka. https://jabar.bps.go.id. Diakses pada 13 Desember 2016.

Badan Pusat Statistik Provinsi Jawa Barat. 2016. Kecamatan Kadudampit dalam Angka. Diakses 19 Maret 2017.

Badan Pusat Statistik. 2015. Statistik Harga Produksi pertanian Subsektor Tanaman Pangan, Hortikultura, dan Tanaman Perkebunan Rakyat. https://bps.go.id. Diakses pada 03 Agustus 2017. 
Baye, M. 2010. Managerial Economics and Business Strategy. Seventh Edition. McGraw-Hill Irwin: Singapura.

Case, K.C, Fair, R.C and Oster,S.M. 2012. Principles of Economics Tenth Edition. Prentice Hall New York.

Dahl, D.C, J.W. Hammond. 1977. Market and Price Analysis. New York: MC. Graw Hill.

Direktorat Jenderal Hortikultura Kementrian Pertanian Republik Indonesia. 2014. Laporan Kinerja Direktorat Jenderal Hortikultura Tahun 2014.

Jaya, W.K. 2001. Ekonomi Industri. Edisi Kedua. Badan Penerbit Fakultas Ekonomi Universitas Gajah Mada: Yogyakarta.

Kementrian Pertanian. Rencana Strategis Kementrian Pertanian Tahun 20152019.

Limbong, W.H, Sitorus, P. 1987. Pengantar Tataniaga Pertanian Jurusan Ilmu-ilmu Sosial Pertanian. Fakultas Pertanian. IPB. Bogor.

Pindyct and Rubinfield. 2009. Microeconomics. Fifth Edition. Prentice Hall New York.

Nuhfil, K. 2009. Struktur Pasar. httpnuhfil.lecture.ub.ac.id. Diakses Pada 17 Agustus 2017. Profil Desa Undrus Binangun. 2017.

Wahyuningsih. 2013. Sistem Pemasaran Rumput Laut di Kepulauan Tanakeke, Kabupaten Takalar, Provinsi Sulawesi Selatan: Struktur, Perilaku, dan Keragaan Pasar. [Tesis]. Sekolah Pascasarjana. Institut Pertanian Bogor: Bogor. 